\title{
The Concept Of Taradin In Online Buying The study of surah an-Nisa' Version 29
}

\author{
Nuri Aslami', Nurul Izzah², Azhari Akmal Tarigan3 \\ Email:nuriaslami@uinsu.ac.id¹,urulizzah@iain-padangsidimpuan.ac.id², \\ azhariakmaltarigan@uinsu.ac.id ${ }^{3}$ \\ 1,3Universitas Islam Negeri Sumatera Utara, ${ }^{2}$ Institut Agama Islam Negeri Padangsidimpuan \\ 1,3Jl. IAIN No. 1 Medan Sutomo 20371, Sumatera Utara \\ ${ }^{2}$ Jl. H.T Rizal Nurdin Km. 4,5 Sihitang, Padangsidimpuan, Sumatera
}

\begin{abstract}
Abstrak
Al-Qur'an, sebagai petunjuk dan petunjuk bagi manusia, menuntut umat Islam untuk memahami ayat-ayat Al-Qur'an. Al-Qur'an telah menetapkan aturan bagi manusia dalam mencari rezeki, salah satunya dengan cara muamalah atau berdagang (jual beli). Trading tidak boleh dilakukan dengan keinginan yang sia-sia. Allah melarang manusia memakan harta orang lain dan merugikan orang lain dengan cara yang batil. Jual beli atau jual beli harus berdasarkan an-taradin' atau kerelaan antara kedua belah pihak. Penelitian ini bertujuan untuk menganalisis konsep 'an-taradin dalam jual beli online yang mengacu pada tafsir Al-Munir oleh Wahbah az-Zuhaili. Ini adalah penelitian kualitatif. Analisis data menggunakan studi kepustakaan. Menurut kaidah syariat, hasil penelitian menunjukkan bahwa 'An-taradin atau kesepakatan bersama dalam Surah An-Nisa' ayat 29 adalah kerelaan antara kedua belah pihak. Kemauan bersama harus mengikuti batasan syariah. Transaksi jual beli online dituntut memiliki etika terbuka dan kepercayaan dalam bertransaksi agar tidak merugikan kedua belah pihak. Kejujuran dan manfaat dapat menjadi prinsip dasar dalam melakukan transaksi jual beli online.
\end{abstract}

Kata kunci: Al-Munir, Online, Taradin, Tijarah

\begin{abstract}
Abstrak
The Qur'an, as a direction and guide for humans, requires Muslims to understand the verses of the Qur'an. The Qur'an has set rules for humans in seeking sustenance, one of which is by way of muamalah or trading (buying and selling). Trading should not be done with the will of vanity. Allah forbids humans to eat other people's property and harming others in a vanity way. Trading or buying and selling are required to be based on an-taradin' or the willingness between the two parties. This study aims to analyse the concept of 'an-taradin in online buying and selling, which refers to the interpretation of Al-Munir by Wahbah az-Zuhaili. This is a qualitative study. The data were analysed using a literature study. According to Shari'a rules, the results showed that 'An-taradin or mutual consent in Surah An-Nisa' verse 29 is the willingness between the two parties. Mutual willingness must be following the limits of sharia. Online buying and selling transactions are required to have open ethics and trust in the transaction to avoid the detrimental of both parties. Honesty and benefit can be the basic principles in conducting online buying and selling transactions.
\end{abstract}

Keywords: Al-Munir, Online, Taradin, Tijarah

\section{Introduction}

Islam has established the essential points of the buying and selling transaction system in its knowledge, namely muamalah (activities that involve humans with each 


\section{The Concept Of Taradin In Online Buying The study of surah an-Nisa' Version 29}

Nuri Aslami, dkk

other)(Shihab, 2007). Buying and selling is a necessity, often with the passage of time and era. Some Prophet Muhammad's companions also became very successful entrepreneurs, including Abu Bakr, Uthman bin Affan, Abdurrahman bin Auf, etc.

In the Qur'an, many terms are found that express the meaning of trade. Trade is expressed through three words, namely tijarah, bay' and syira'. The word tijarah is found in 7 surahs in the Qur'an, including QS. An-Nisa: 29, QS. Al-Baqarah: 16, QS. Al-Shaff:10-11, QS Al-Nur: 30, QS. At-Taubah: 24, QS. Fatir: 29-30, QS. AlJumuah: 11 (Fauziah, 2017).

One form of muamalah is buying and selling transactions described in the Qur'an, one of which is An-Nisa verse 29, which reads:

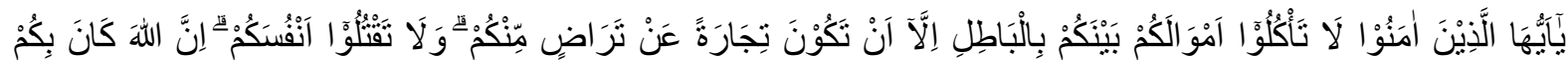

"O, you who believe, do not eat your neighbour's property in a wrong way (wickedness), except in the form of commerce based on mutual consent between you. Do not kill yourself. Verily Allah is Most Merciful to you." (QS. An-Nisa: 29) (Departemen Agama RI, 2019).

The verse explains the rules for seeking sustenance at will and in the wrong ways, such as fraud, cheating, perjury, and other vanity acts. The Qur'an provides a dividing line between what is allowed and not allowed in seeking life supplies. Focusing on the public benefit, such as the willingness consent between the two parties, no party feels aggrieved and oppressed in the transaction to bring mutual benefits between individuals, willingly and fairly, are justified(Veitzal Rivai, Nuruddin, \& Arfa, 2012).

Allah and the Prophet Muhammad have determined the exchange of goods by agreement between the two parties in a trade transaction as permissible and prohibits taking other people's objects without their consent and permission(Haris, 2004).In trading, paying attention to the condition of the buyer is also an important thing to do. Trade must be free from the elements of fraud and coercion. Thus, trades must follow the consensual principle ('an taradin minkum). The willingness consent is measured by ijab and qabul (consent and acceptance). All forms of executed trade on a consensual basis are permitted or halal(Tarigan, 2019).

The development of the times and technology today has influenced many aspects of human life. The internet, which is overgrowing, has comforted all people 
and provides many benefits for the community. Internet technology has a significant impact on human behaviour, interaction, and relations. Technology users in Indonesia are overgrowing and have reached 71.17 million people. Compared to Indonesia's total population, the number of internet users in Indonesia is 64.8 per cent. Technological sophistication has influenced people's behaviour and perspective in their lives(Mudawamah, 2020). Advances in technology have made it easier for society in many ways. Technology lead community activities to be more effective and efficient.

Online buying and selling transactions are known as-salam transactions, a form of transaction with cash or an expedited payment system, but the delivery of goods is suspended. In the as-salam transaction, it is reflected that there is mutual help that can benefit both parties by paying attention to the aspect of willingness between the two parties. As-salam transactions are described in the hadith, which means:

"Whoever performs as-salam in the transaction of buying and selling dates, then let him do it with clear measurements and clear scales." (HR. Bukhari)(Abu Abdillah Mumammad bin Ismail Al-Bukhari, 2021)

The mechanism of online buying and selling can harm one party, either the buyer or the seller. Many aspects potentially contribute to unhealthy buying and selling transactions because there is fraud between the seller and the buyer.

From an Islamic perspective, online buying and selling transactions have many pros and cons. According to the Ash-Shafi'i perspective, buying and selling are allowed because the goods have been witnessed first. According to most scholars among friends and tabi'in, the sale and purchase that cannot be witnessed directly are invalid because they contain fraud elements that endanger one party(Pekerti \& Herwiyanti, 2018).

Buyers in online buying and selling cannot directly check the goods to be purchased, so it is possible that when the goods arrive in the hands of the buyer, the purchased goods do not match the description or characteristics of the goods displayed in the marketplace application. The implementation of online buying and selling is based on a mutually willing spirit between the seller and the buyer(Iqbal \& Idris, 2021). Online buying and selling can provide convenience and benefit to the community. There must be honesty, fairness, and clarity by providing complete 


\section{The Concept Of Taradin In Online Buying The study of surah an-Nisa' Version 29}

Nuri Aslami, dkk

data, and there is no intention to deceive or harm others. This convenience and advantage will not be obtained both parties avoid following strict cultural and legal ethics. Thus, they would not be trapped in greed and injustice(Salim, 2018).

In general, an taradin minkum is giving a precondition that a trade can be held with two things: the trade should be made based on mutual willingly between the parties and may not be beneficial to one party at the expense of others, should not hurt each other, both for yourself and others. Surah An-Nisa' Verse 29 also understands that everyone should not harm others for their interests because the party who does that seems to suck his blood and pave the way for destruction for himself.

This article discusses the interpretationof'antaradin minkum' in QS. AnNisa': 29 with relevance to online buying and selling transactions. To date, 'an taradin minkum' is only discussed in a Muamalah or Islamic Economic book. Some Muslims do not understand the doctrines and knowledge in the Qur'an. Many Muslims read Quran as a daily routine, but they do not do "taddabur" and understand the meaning inside. As a result, the knowledge contained in the Qur'an seems challenging to apply in everyday life. This can be seen from the many activities of Muslims, especially in buying and selling transactions, especially online buying and selling transactions which are very far from the values of taradin minkum in QS. An-Nisa': 29. This article refers to Tafsir AlMunir, which is a contemporary book of commentary.

Interpretation of sura An-Nisa' verse 29 focuses on 'an taradin minkum' requiring significant contextualisation and relevance to online buying and selling transactions. Al Munir commentary book by Wahbah Az-Zuhaili stated that the willingness between two parties in QS. An-Nisa' verse 29 is the willingness between two parties according to shariah; in other words, not all willingness is based on shariah. Al-Misbah commentary also explains that willingness is hidden in the heart, but the indicators and signs can be seen. Ijab and Qabul, or anything known in customs as handovers, are forms used by the law to show willingness(Shihab, 2002). Therefore, each other willingness must comply with sharia restrictions. Riba from buying and selling and the debt and gambling as the advantage of trading is haram and not halal according to sharia. 
Thus, Tafsir Al-Munir (Al-Munir commentary) and Tafsir Al-Misbah (AlMisbah commentary) are not only emphasising muamalah or buying and selling transactions. Both interpretations also emphasise the necessity of willingness because the most important element in buying and selling transactions is the willingness between the two parties, namely the seller and the buyer. An taradin minkum or willingness between the two parties will ensure that no party is harmed and oppressed in the transaction. It is hoped that the transaction will be a way that bring benefits and justice(Malik, 2021).

\section{Literature Review}

\section{Online Buying and Selling}

Buying and selling in Islamic law is something that is allowed, as the word of Allah in Surah Al-Baqarah verse 275, namely:

Meaning: "And Allah justifies buying and selling and forbids riba..." (Al-Baqarah: 275) (Departemen Agama RI, 2019).

Some other scholars give the meaning of buying and selling, including First, according to the Hanafiyah scholars, it is the exchange of property (objects) with assets based on special (allowed) methods. Second, according to Imam Nawawi in AlMajmu, property exchange with property for ownership(Muhammad, 2004).Third, according to Ibn Qudamah in the book al-Mughni, it is the exchange of property with property to make each other's property.

Online buying and selling is a business that is run through the internet(Lingga, 2011). The term online business is increasingly popular with the term of $E$ Commerce or electronic commerce.E-Commerce is a combination of two words which is Electronic Commerce. E-commerce itself can be interpreted as a business activity involving consumers, manufacturers, service providers and intermediary traders using internet facilities. Triton Prawira Budi defines E-Commerce as electronic commerce in which trading transactions, both buying and selling, are carried out electronically on the internet network(Budi, 2008).

\section{Taradin Concept (Willingness)}

Talking about the concept of taradin (willingness), it is an inseparable part of any transactional contract regardless of its form and type. 'An taradhin consists of two syllables; 'an and taradin. Taradin comes from taradhaya, yataradhayu, 
taradhuyan equivalent to tafa'ala, yatafa'alu, tafa'ulan(Anis, 1972), which means like (Al-Marbawi, 1350).Using bina musyarakah shows the meaning of mutual consent or agreement(Baalbaki, 1997).The addition of the letter "an" indicates that the consensual principle must arise from the heart's desire of each party, as evidenced by the existence of consent and qabul, not consensual in a formal sense.

Al-Shafi'iy argues:

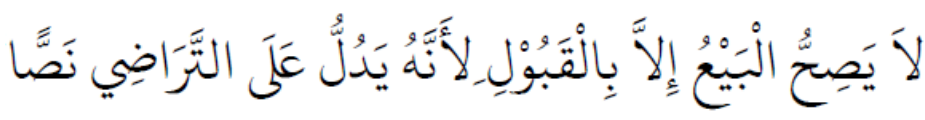

Meaning: It is not valid to buy and sell except by handing over because that indicates like and liking.

Juahaya, S. Praja, explained that taradin is one of the principles of muamalah, which applies to every form of muamalah between individuals or parties. Therefore, muamalah activities must be based on the willingness of each. Willingness here means the willingness to do something in the form of muamalah and willingness in the sense of receiving and or surrendering assets that are used as objects of engagement and other forms of muamalah (Shihab, 2002).

M. Quraish Shihab, in his commentary, explains the meaning of taradin. He interprets that in buying and selling, consensual attitudes are highly demanded and required (Shihab, 2002)or in the sense that there must be a pleasure. The signs of pleasure cannot be known outwardly but can be seen through the ijab and qabul declared by the parties before they parted. The statement of ijab and qabul can be realised in various forms, the most important of which is verbal. However, it should be noted that, in certain circumstances, verbal statements are replaced by writing or actions, as has been happening recently, namely the E-Commerce business (Burhanuddin, 2009).Pleasure is achieved if there is a conformity of will between the two parties. The statement of the will is not limited to the pronunciation of words alone but can be achieved by giving signs that can translate the will(Zein, 2009). Pleasure shows that no party has been wronged and offended, and each party is sincere.

\section{Taradin Mechanism in Islamic Economic Perspective}

Several principles in Islam relating to muamalah contracts or buying and selling transactions are: First, the principle of the willingness of all parties involved (taradin ). Therefore, every transaction made because of the element of coercion and 
pressure is not legal. Second, the prohibition of fraud and counterfeiting practices, including in this case consuming other people's property in a vanity manner, such as taking an oath. Third, the agreement is carried out thoughtfully and consistently (Utomo, 2003).

Everyone has the right to determine the object, content, or material of any desired transaction. However, in order for an economic transaction to be in line with the provisions of Islamic Shari'ah and have legal consequences according to syar'i, it must adhere to the following basic principles: 1) Binding Principles, 2) Free Will Principles, 3) Honesty Principles, 4) Halal Principle.

\section{Methods}

The research method in this article used a literature study(library research). Literature studies have an important role in any research. All research requires a literature search to obtain the data needed to complete a study. A literature study is a type of research used to collect in-depth information and data through various literature relevant to research. Literature studies are related to theoretical studies and several references that cannot be separated from the scientific literature(Sugiono, 2012). The steps taken in library research consist of 4 stages, namely, 1) preparing equipment, 2) compiling a bibliography work, 3) managing time, 4) reading and creating research notes(Zed, 2004).

The data sources used in this study were obtained from various relevant literature such as books, journals, notes, papers, or articles related to the research focus. Data analysis was carried out in several stages: data collection, data reduction, data presentation, concluding, and data verification. The collected data and information were analysed to answer research questions.

\section{Result And Discussion}

\section{Biography of Wahbah Az-Zuhaili}

Wahbah az-Zuhaili's full name is Wahbah Mustafa az-Zuhaili. He was born in the village of Dir 'Athiyah, Damascus, on March 6 ${ }^{\text {th }}$, 1932. Wahbah az-Zuhaili's parents were well known for their piety and firmness in their religion. His father, who memorised the Qur'an, was Mustafa az-Zuhaili and his mother was Fatima bint Mustafa Sa'adah. 


\section{The Concept Of Taradin In Online Buying}

The study of surah an-Nisa' Version 29

Nuri Aslami, dkk

\section{The Works of Wahbah Az-Zuhaili}

Wahbah az-Zuhaili is a contemporary fiqh scholar whose thoughts spread throughout the world by his fiqh books. Wahbah az-zuhaili taught at the University of Damascus starting in $1963 \mathrm{M}$ and at various universities in Arab countries such as Benghazi, Libya, etc. Wahbah az-Zuhaili is very productive in producing scientific papers and journals. Among his most important works include Al-Fiqh Al Islami wa Adillatuh, At Tafsir Al-Munir, Al Fiqh Al Islami fi Uslubih Al Jadid, Nazariyat Adh Dharurah Asy Syari'ah, Usul Al Fiqh Al Islami, Az Zhara'ah fi As Siyasah Asy Sharia, and so on.

\section{Al-Munir's Interpretation Method}

Darul-Fikr published tafsir Al-Munir written by Wahbah az-Zuhaili in Damascus. Al-Munir's Tafsir was written in 15 volumes and translated into several languages and printed many times. This proves that Al-Munir's interpretation has become a concern in various worlds (Wahbah Az-Zuhaili, 2013).

Wahbah az-Zuhaili in every verse interpretation always begins with an explanation of the virtue and content of the verse and several themes related to it in outline. The form of interpretation is a combination of bi al-riwayah and bi al ra'yi. At the same time, the method of interpretation is the tahlili method (Sayyid Mumammad Ali Ayazi, 1993). Moreover, the style of interpretation is al-adabi al ijtima' (literature and social society) and al-fiqhi (Islamic laws). This is because Wahbah az-Zuhaili has a scientific background in the field of fiqh. The style of language and editorial presented in the interpretation is very thorough and adapted to the situation that is developing and needed by the community.

\section{Analysis of Taradin's Interpretation in Online Buying and Selling In QS} An-Nisa': 29

Contemporary interpretation paradigms tend to contextualise the meaning of the verses of the Qur'an by taking universal principles and ideas. Therefore, the verses from the Qur'an, which are considered less relevant in their interpretation with the times, the interpreters in contemporary times are trying to continue to interpret the Qur'an according to their times.

Surah An-Nisa' is said to be proof of the exaltation of Islam towards women. Naming (at-tasmiyah ) as An-Nisa' letter is seen as a perpetuation of history, how the Al-Qur'an is here to provide teachings that take sides or at least pay attention 
to women. The surah, which ranks fourth in the composition of the Ottoman Mushaf, is classified as a madaniyyah surah. So it should be a madaniyyah letter. It contains various Shari'ah laws, which regulate the internal and external affairs of the Muslims, such as; family, woman, household, state, and society, QS. An-Nisa' also discusses accounts payable, buying and selling, economics and others(As. Suyuthi, 2008).

Buying and selling are among the best and noblest muamalah (transactions) between people in social life. Even though there are many ways to find sustenance, but buying and selling are categorised as noble businesses because buying and selling often occurs in social life(Wahbah az Zuhaili, 2006).businesses because buying and selling often occurs in social life (Wahbah az Zuhaili, 2006). The goods must have conditions for trading: First, the goods must be in a holy and halal condition. This means that there is no willingness when goods are sold, such as stolen goods, pork, and so on, which are forbidden in the Qur'an. Second, the goods being traded must be researched first. Accuracy in buying and selling is essential to avoid losses between both parties. Third, the item belongs to someone. Fourth, the condition of the goods being traded is the goods that are not in the process of being offered by someone else. The main element in buying and selling is mutual acceptance (an-taradin) without any element of fraud.

The wordis derived from Arabic, namely, the word رضييرضرضin oral Arabic which means like, willingly, agreeing(Rohman, 2016). In al-Munawwir's dictionary تراضmeans agreement from both parties or mutual acceptance(Munawwir, 1997). That is a condition where each party carrying out the contract has agreed to give up on something that is the object of the contract. So that a person's freedom in carrying out the contract can be protected according to his own will and choice. In the case of buying and selling, the Qur'an specifically mentions the word an-taradin in the QS. An-Nisa': 29

In the Mu'jam Mufradat fi Alfaz Al-Qur'an by Ar-Ragib Asfihani, 11 verses have the root word of رضي, but only three verses have تفعل fill mudhari' which means mutual or interaction between two or more parties. The three verses are: QS AlBaqarah: 232, QS Al-Baqarah: 233, QS An-Nisa ': 29.

Wahbah Az-Zuhaili in Al-Munir's interpretation explains that what is meant by 'an-taradin or mutual consent in verse 29 of Surah An-Nisa' is the willingness between the two parties based on the rules of the shariah, in other words, basically 
not all of the mutual consent is syar'i recognised. Therefo following the limits of sharia. In this case, online buying an

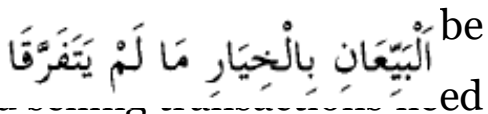
transaction ethics to avoid harmful things between the two parties. Therefore, the main element in buying and selling transactions is willingness without coercion, followed by transaction ethics.

In the interpretation of Al-Misbah تشرillingness is something that is hidden in the heart, but the indicators and signs can be seen. Willingness is realised with consent and acceptance or ijab and qabul. Ijab and qabul can also be shown by handing over according to the customs that develop in the community. The handover has shown a willingness between the two parties(Shihab, 2002).

In muamalah transactions, it is required to heed the established rules and not to do anything that isal-bathil (بالباطل), a violation of religious provisions or agreed conditions. In this context, the Prophet Muhammad said, "Muslims are following (must fulfil) the conditions they agreed upon, as long as they do not allow what is haram (changing haram into halal) or forbid what is lawful or halal."

In the Book of Tafsir Al-Munir it is stated that Imam Ibn Farir at-Tabari narrated from Maimun bin Mahran that the Prophet Muhammad said,

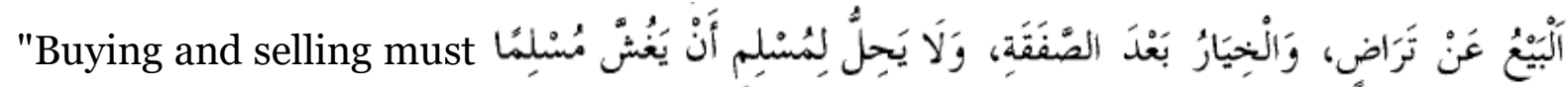
if there are defects) after the contract, and a Muslim may not deceive other Muslims ." (HR. Ibn Jarir).

For the perfection of the principle of consensual, khiyar majlis (considering goods to be sold or bought or not) must be carried out as explained by Imam ashShafi'i, Ahmad, al-Laits, and others. The proof is the hadith contained in the book Sahih Bukhari and Muslim, which states that the Prophet Muhammad said,

"Two sellers and buyers must do khiyar while they have not separated." (HR. Bukhari and Muslim)

In Sahih Bukhari, it is stated that,

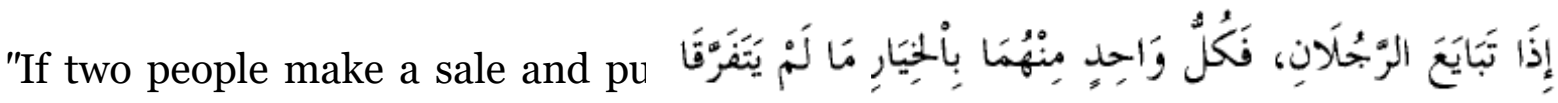
khiyar as long as they have not separated." (Narrated by Bukhari and Muslim) 
Thus, the general meaning of the above verse is limited by the description of the hadith. Included to perfect the principle of consensual consent is the stipulation of the khiyar rule for three days from the day of the contract execution. According to the majority of scholars other than Shafi'i madhhab, buying and selling of mu'aatah (buying and selling without the shighat of the contract or akad by both parties) is considered to show the willingness of the two parties to make the transaction.

The Hanafi and Maliki scholars do not recognise the legality of the khiyar majlis because the verse above has determined that the goods being sold have changed ownership with the sale and purchase contract being carried out voluntarily, both the seller and the buyer are still in one place or have separated. In addition, what is meant by a sale and purchase contract is a procession of giving and receiving (ijab and qabul), which is carried out by two parties who transact, not the gathering or separation of the two parties which carry out buying and selling transactions(Wahbah Az-Zuhaili, 2013).According to Wahbah Zuhaili, assalam transactions can be submitted using modern communication tools. Therefore, the transaction is a legitimate and new transaction model(Wahbah az Zuhaili, 2006).

Many contemporary scholars think that transactions with modern tools are valid if there is clarity in the transaction. Sheikh Muhammad Bakhit al Muthi'i, Mushthofa az Zarqa', Wahbah Zuhaili and Abdullah bin Mani'. This is based on the opinion of many scholars who stated that transactions via correspondence were valid and if the ijab (statement of the first party) was valid after the letter arrived in the hands of the second party. Tafsir Al-Munir states that it is permissible for all kinds of trade intended for an advantage on the condition that both parties are willing. All compensation waivers in buying and selling in any way, whether it is detrimental to someone, must be compensated(Wahbah Az-Zuhaili, 2013).

According to Syamsul Anwar, there is what is called a consensual contract in contract law. This type of contract means an agreement between the parties without the need for certain formalities. However, this does not prevent the validity of the contract. According to Imam Al-Bajuri, written and gestured expressions are a form of taradin in buying and selling transactions(Muzakkir \& Falah, 2016).Indications of the achievement of willingness are of various types according to the times, not limited to verbal but also by signs, writing, etc. The most important thing is to prove a willing attitude in the transaction(Mardani, 2011).This is based on the word taradin; when 


\section{The Concept Of Taradin In Online Buying The study of surah an-Nisa' Version 29}

Nuri Aslami, dkk

viewed from a language perspective, the sentence uses the form of nakirah. The author agrees with what he said that the word taradin is a form of nakirah. Nakirah in Arabic linguistics means general. Thus, the form of willingness cannot be specified in a specific form.

In contrast to the opinions of scholars such as Syafi'iyah, Shi'a and Dzahiriyah, they understand that the form of willingness is in the form of oral speech. Thereforethey require a contract in buying and selling as previously quoted. Similarly, in salam transactions, money must be transferred immediately after the transaction is carried out in salam transactions.

The connection with the concept of willingness and indications of the achievement of that will can be seen in actual transactions. This problem will arise when the concept is faced with an online business (E-Commerce). The rapid growth of internet technology has made online commerce also increasing (Chan \& Al-Hawamdeh, 2002). According to syar'i, in this case, online buying and selling are carried out legally and especially. For instance, the ijab and qabul in online buying and selling are not done face to face in one place, but through internet media. In the book of Al-Munir's commentary, part of the perfection of a willingness to buy and sell there is khiyar majlis, namely the right to choose an item sold in one place. Thus, online buying and selling transactions using media intermediaries are still willing. This is because the understanding of Ijab and Qabul, which is carried out in one assembly and the right to vote in a place, is not only defined by a direct meeting between the seller and the buyer but is conditional. Tafsir Al-Misbah interprets that Ijab and Qabul, or anything is known in customs as handovers, are forms used by the law to show willingness. In online buying and selling transactions or conventional buying and selling, the most important thing is that there is a willingness between the two parties.

In the transaction, the seller is not allowed to be free to make a contract but is limited by various rules that Allah has set in the Qur'an. Allah has warned that humans should not eat other people's property with vanity. This means that it is not permissible to eat other people's property in a way that is not justified on the principle of harming other parties, whether it is prohibited in the texts based on ijtihad or nahs. In general, it can be said that eating wealth with vanity is contrary to the provisions based on willingness that can harm both parties, such as fraud and the 
prohibition of usury. In this regard, open ethics and honesty are needed in online transactions. The seller mentions the advantages of the product being sold and mentions the shortcomings to avoid fraud. The specifications are explained in detail because buying and selling online only relies on trusted capital.

Regarding the trust of the perpetrators of online buying and selling, buying and selling transactions need to show the willingness between the two parties without harming one of them based on trust. The parties involved must adhere to Islamic principles, transactions must be carried out in the right way, and clarity in communication(Shamim, 2010).So that the seller is not allowed to exploit consumer ignorance. Concealment of information can be a reason for consumers to cancel the contract if later it is found out that information about the specifications of the goods is not true. Thus, the main element of online buying and selling transactions is mutual willingness between the two parties, in Al-Munir's interpretation emphasising that not all mutual willingness is following the sharia. This is in order to fulfil the need for ethics in online buying and selling transactions, while in Al-Misbah's interpretation stated when the seller and the buyer has carried out the Ijab, and Qabul or anything is known in customs as a form of handovers suchas online buying and selling transactions, there is mutual willingness between the two parties.

Ijab and Qabul, as a manifestation of the willingness of both parties, can be done through oral, written, gestures or actions that are customary in Ijab and Qabul. Implementation of the statement of the agreement between taradin or willingness to buy and sell online as a form of willingness can be expressed in media available on the internet network (Muzakkir \& Falah, 2016). A statement of agreement to show their will can be done through media chat, video conferencing, and hosting. Product specifications and payment procedures up to the delivery process are explained with these media. Some online buying and selling actors also use the website. In this media, the buyer in making a transaction must go through several stages. Buyers can see product specifications and payment methods provided by the seller on the website. Buyers who want to proceed to the payment stage must click the approval button after passing several instructions and terms, which usually end with the word "agree" as a sign of agreement to proceed to the payment and product delivery stage. This process has shown an agreement marked by the willingness between the two parties who transact in online buying and selling. Thus, 
" an-taradin in online buying and selling can be applied by sellers and buyers through various media available on the internet.

\section{Conclusion}

Allah has set the rules in buying and selling as described in the Qur'an QS. AnNisa': 29. Buying and selling transactions must be protected from fraudulent practices, fraud, perjury and other vanity acts. Information technology has brought the development of trading, buying, and selling into a new phase, such as buying and selling online. All forms of trading or buying and selling are allowed and permissible while still complying with the principles of consensual or 'an-taradin minkum and avoiding things that are vanity. In Al-Munir's interpretation, all forms of trade that aim to gain profit on the condition that there is willingness between the two parties are allowed. The interpretation of 'an taradin minkum in online buying and selling according to QS An-Nisa: 29 is interpreted to be mutually willing without harming any party. Every transaction made must be avoided from things that have the potential to harm themselves or others. QS An-Nisa verse 29 has been clearly emphasised that it is not permissible to harm others for self-interest. The parties involved in online buying and selling transactions must have the ethics of openness and honesty. Honesty and benefit can be the basic principles in conducting online buying and selling transactions.

\section{Reference}

Abu Abdillah Mumammad bin Ismail Al-Bukhari. (2021). Shahih Bukhori. Digital Library : Maktabah Syamilah.

Al-Marbawi, M. I. A. R. (1350). Qamus al-Marbawi. Mesir: Dar al-"Ulum.

Anis, I. (1972). . Al-Mu "jam al-Wasith. Kairo: Dar al-Maearif.

As. Suyuthi, J. (2008). Sebab Turunnya Ayat Al-Quran. Depok: Gema Insani.

Baalbaki, R. (1997). Al-Mawarid, A Modern Arabic - English Dictionary. Beirut Lebanon: Dar al-„,Ilm Lilmalayin.

Budi, T. P. (2008). Bisnis Lewat Internet. Jakarta: Oryza.

Burhanuddin, S. (2009). Hukum Kontrak Syariah. Yogyakarta: BPFE. 
Chan, B., \& Al-Hawamdeh, S. (2002). The development of e-commerce in Singapore: The impact of government initiatives. Business Process Management Journal, 8(3), 278-288. doi: 10.1108/14637150210428970

Departemen Agama RI. (2019). Al-Qur'an dan Terjemahnya.

Fauziah, C. (2017). At-Tijarah (Perdagangan) Dalam Alquran (Studi Komparatif Tafsir Jami' Li Ahkam Alquran dan Tafsir Al-Mishbah). Jurnal At-Tibyan: Jurnal Ilmu Alqur'an Dan Tafsir, 2(1), 76-96. doi: 10.32505/attibyan.v2i1.253

Haris, F. A. (2004). Transaksi Bisnis E-Commerce Perspektif Islam. Yogyakarta: Magistra Insania Press.

Iqbal, M., \& Idris, M. (2021). Tinjauan Hukum Islam Terhadap Sampel Dalam Jual Beli Online (Studi Pendapat Mazhab Hanafi, Mazhab Maliki, Mazhab Syafi'i, Mazhab Hambali). FAWAID: Sharia Economic Law Review, 3(1). Retrieved from https://ejournal.iainkendari.ac.id/index.php/fawaid/article/view/3090

Lingga, B. (2011). Smart Business Online: Solusi Cerdas Belajar Bisnis Online. Bekasi: Laskar Aksara.

Malik, A. (2021). Perspektif Tafsir Konteks Aktual Ekonomi Qur'ani dalam QS alNisa'/4: 29. Dirasat Islamiah: Jurnal Kajian Keislaman, 2(1), 39-56. doi: 10.5281/zenodo.5166465

Mardani. (2011). Hukum Ekonomi Syariah. Bandung: Refika Aditama.

Mudawamah, N. S. (2020). Perilaku Pengguna Internet: Studi Kasus Pada Mahasiswa Jurusan Perpustakaan Dan Ilmu Informasi Uin Maulana Malik Ibrahim. BIBLIOTIKA: Jurnal Kajian Perpustakaan Dan Informasi, 4(1), 107-113.

Muhammad. (2004). Etika Bisnis Islami. Yogyakarta: UPP AMK YKPN.

Munawwir, A. W. M. (1997). Kamus Arab-Indonesia. Surabaya: Pustaka Progressif.

Muzakkir, S., \& Falah, S. T. I. S. D. (2016). Impelementasi Asas Tarâdin dalam Bisnis Online (Telaah Surat An-Nisa Ayat 29).

Pekerti, R. D., \& Herwiyanti, E. (2018). Transaksi Jual Beli Online dalam Perspektif Syariah Madzhab Asy-Syafi'i. Jurnal Ekonomi, Bisnis, dan Akuntansi, 2o(2). doi: 10.32424/jeba.v20i2.1108

Rohman, A. (2016). Menyoal Filosofi 'An Taradin Pada Akad Jual Beli (Kajian Hukum Ekonomi Syariah Dalam Transaksi Jual Beli). Et-Tijarie: Jurnal Hukum Dan Bisnis Syariah, 3(2). 
Salim, M. (2018). Jual Beli Secara Online Menurut Pandangan Hukum Islam. Al Daulah: Jurnal Hukum Pidana Dan Ketatanegaraan, 6(2), 371-386. doi: 10.24252/ad.v6i2.4890

Sayyid Mumammad Ali Ayazi. (1993). Al-Mufassirun Hayatun wa Manhajuhum. Teheran: Wizanah al-Tsiqafah al-Insyaq.

Shamim, A. (2010). E-commerce from an Islamic perspective. Journal of Islamic Marketing, 1(2). doi: 10.1108/jima.2010.43201bae.001

Shihab, M. Q. (2002). Tafsir Al-Misbah Pesan, Kesandan Keserasian Al-Qur'an. Jakarta: Lentera Hati.

Shihab, M. Q. (2007). Secercah Cahaya Ilahi. Bandung: Mizan.

Sugiono. (2012). Metode Penelitian Kuantitatif Kualitatif dan R\&K. Bandung: Alfabeta.

Tarigan, A. A. (2019). Tafsir Ayat-Ayat Ekonomi. Medan: FEBI UIN-SU Press.

Utomo, S. B. (2003). Fiqh Aktual, Jawaban Tuntas Masalah Kontemporer. Jakarta: Gema Insani.

Veitzal Rivai, Nuruddin, A., \& Arfa, F. A. (2012). Islamic Business and Economic Ethic Mengacu pada Al-Qur'an Jejak Rasulullah SAW dalam Bisnis, Keuangan, dan Ekonomi. Jakarta: Bumi Aksara.

Wahbah az Zuhaili. (2006). Al-Fiqhul Islamy Wa Adillatuhu, Terjemahan. Bandung: Pustaka Media Utama.

Wahbah Az-Zuhaili. (2013). Al Tafsir al-Munir fi al-Aqidat wa al-Syariat wa almanhaj. Jakarta: Gema Insani.

Zed, M. (2004). Metode Penelitian Kepustakaan. Jakarta: Yayasan Obor Indonesia.

Zein, Y. A. (2009). Kontrak Elektronik \& Penyelesaian Sengketa Bisnis ECommerce. Bandung: Mandar Maju. 